\title{
DO AMOR COMO PRINCÍPIO E DA FILOSOFIA COMO SALVAÇÃO: PRESSUPOSTOS DE UMA ESPIRITUALIDADE LAICA
}

\author{
${ }^{1}$ Douglas Willian Ferreira \\ Universidade Federal de Juiz de Fora (UFJF) \\ (D) https://orcid.org/0000-0002-6190-6370
}

\begin{abstract}
RESUMO:
Num momento em que a fé e as instituições religiosas parecem caducar temos como movimento oposto a valorização da espiritualidade, pelo menos no que tange à proposta filosófica de Luc Ferry. Secularizando o amor cristão, o autor nos apresenta uma filosofia que é capaz de salvar o homem através do sentido que dado à vida, ou seja, não se espera ser salvos por um absoluto existente fora do mundo, mas a salvação depende unicamente do homem. Nesse sentido, à medida em que fazemos escolhas e projetos individuais, liquidamos com toda forma de pensamento determinista. Neste aspecto, cabe à espiritualidade a tarefa de despertar o homem para a necessidade de se afirmar enquanto sujeito e ao mesmo tempo sair de si mesmo, em direção ao outro, como confirmação de uma espiritualidade laica pautada na compaixão e no amor. No entanto, não se trata de uma espiritualidade sentimentalista, mas antes, uma espiritualidade em conformidade com a tradição filosófica e com a racionalidade humanista. Dessa forma, o espiritual não estará relegado ao âmbito privado, mas alcançará até mesmo as ações políticas e a vida social. Finalmente, perceberemos que essa espiritualidade laica que fundamenta as ações humanitárias e a própria relação familiar se assemelha em muitos aspectos com a proposta agápica do amor cristão.
\end{abstract}

PALAVRAS-CHAVES: Luc Ferry; Soteriologia; Espiritualidade; Imanência; Amor.

\section{LOVE AS A PRINCIPLE AND PHILOSOPHY AS SALVATION: ASSUMPTIONS OF A SECULAR SPIRITUALITY}

\footnotetext{
${ }^{1}$ Mestrando em Ciência da Religião na Universidade Federal de Juiz de Fora (UFJF), Minas Gerais - Brasil. E-mail:: douglasinvictus@ hotmail.com
} 


\begin{abstract}
:
At a time when faith and religious institutions seem to have lapses we have as opposed moving the appreciation of spirituality, at least with regard to the philosophical proposal of Luc Ferry. Secularising Christian love, the author presents us with a philosophy that is able to save man through the sense given to life, that is not expected to be saved by an existing absolute outside of the world, but salvation depends only on man. In this sense, as we make choices and individual projects, we liquidate all forms of deterministic thinking. In this respect, it is the task of the spirituality to awaken man to the need to assert itself as a subject while leaving himself toward the other, as confirmation of a secular spirituality guided by compassion and love. However, it is not a sentimental spirituality, but rather a spirituality in accordance with the philosophical tradition and the humanistic rationality. Thus, the spirituality will not be relegated to the private sphere, but will reach even the political action and social life. Finally, we realize that this secular spirituality that underlies humanitarian actions and its own family relationship is similar in many ways to the agapic proposal of Christian love.
\end{abstract}

KEYWORDS: Luc Ferry; Soteriology; Spirituality; Immanence; Love.

\title{
1. Introdução
}

No pensamento do filósofo contemporâneo, Luc Ferry, vemos uma nítida distinção entre moral e ética. Enquanto a moral se apresenta como um conjunto de imperativos e proibições tendo como finalidade direcionar nossas ações e responder à pergunta "que devo fazer? ", a ética nos conduz à esfera da reflexão filosófica, levando os indivíduos à pergunta sobre o próprio sentido da existência bem expressa na seguinte formulação kantiana: "o que nos é permitido esperar?"

A significação da vida através da realização de grandes projetos não faz mais sentido. As religiões com suas promessas de eternidade; as revoluções e suas promessas de um mundo igualitário transformaram-se em absurdos. É através da escolha livre e da concretização dos pequenos projetos, que o homem do segundo humanismo ${ }^{2}$ consegue significar a própria vida.

\footnotetext{
${ }^{2}$ Luc Ferry faz a distinção que Ferry entre dois humanismos: o Primeiro Humanismo se relaciona àquele gerado pelas propostas iluministas no qual a razão tem um papel fundamental porque é ela que faz do homem um ser excepcional e em muito, superior aos demais seres. Já o Segundo humanismo, criado por Luc Ferry, surge após o processo de desconstrução da metafísica e da secularização moral, e se caracteriza por valorizar, acima da razão, o amor.
} 
Não havendo uma heteronomia institucionaliza, que nos impõe valores e traça nossos projetos, o homem se vê numa situação angustiante, porque se torna o único responsável pelas escolhas que faz. É por isso que se fala de uma crise do dever, afinal, a busca pelo sentido da vida está intimamente relacionada à consciência individual e não a normas imperativas que nos ditam o que devemos ou não fazer. Nesse sentido, as grandes teorias éticas parecem ter sido legadas ao esquecimento, no entanto, Ferry percebe que ao invés de prevalecer essa aparente crise do dever, a ética, após o processo de desconstrução filosófica ${ }^{3}$, se fundamentará na responsabilidade e consecutivamente, na capacidade do homem de amar ilimitadamente todos aqueles que participam de sua humanidade.

Essa responsabilidade é a base da ética do segundo humanismo desenvolvido por Ferry, que se difere do primeiro, porque valoriza o amor à razão, a abnegação e o sacrifício de si em favor da humanidade. Para melhor compreendermos essa proposta, partimos dos pressupostos da moral kantinana, que embasam o secularismo da moral moderna, segundo Ferry. A partir de então, a liberdade tomará as rédeas do comportamento humano convocando esse homem à responsabilidade e ao amor. Por fim, chegaremos aos pressupostos éticos do segundo humanismo, que associa laicidade e espiritualidade, mostrando que ainda é possível ao homem moderno significar a própria vida através do sacrifício que faz de si. É então, nessa íntima relação entre espiritualidade e laicidade que perceberemos o quanto a ética defendida pelo autor carrega consigo o ranço de toda a proposta da tradição cristã.

\section{As importantes considerações de Kant para a constituição da moral laica contemporânea}

Para Ferry, o grande responsável pela secularização da moral é Kant porque coube a ele, bem como aos republicanos franceses, "a noção de virtude desinteressada e a de universalidade" (FERRY; COMTESPOVILLE, 1999, p. 221). No entanto, tais noções só se tornaram possíveis a partir de uma nova visão do homem que surge com o pensamento de Rousseau. De maneira geral, o homem deixa de ser concebido como uma criatura determinada por uma essência prévia, conferida pelo criador, tornando-se, pela liberdade, o único responsável por aquilo que é. Assim, segundo o autor, antes mesmo de Sartre valorizar a precedência da existência sobre a essência, Rousseau já o teria feito quando afirma que o

\footnotetext{
${ }^{3}$ A desconstrução será para Ferry o momento histórico de rupturas acontecidas no século XX ocasionando novas interpretações da moral e da construção do pensamento. Desconstroem-se os valores e as autoridades tradicionais findando com as ilusões difundidas pelos mesmos. Veremos mais adiante que Luc Ferry salienta dois grandes pensadores como os mais importantes desconstrutores de nosso século, a saber, Nietzsche e Heidegger.
} 
homem se diferencia dos demais animais, por sua capacidade de excesso, ou seja, pela sua liberdade. Afinal, somente os seres livres podem buscar o aperfeiçoamento pessoal, que será chamado por Rousseau de "perfectibilidade" (FERRY, 2007, p. 130).

Essa capacidade consciente permite ao homem analisar e julgar suas próprias ações. Não havendo mais a necessidade de um fundamento éticoteológico, a saber, o decálogo do Antigo Testamento, o homem passa a repensar o espaço político e a interação social fundamentado em sua capacidade reflexiva e interesse pelo bem comum, portanto, "temos, então, uma ética fundada no homem" (FERRY, 2012b, p. 34) que dispensa toda a heteronomia religiosa.

Quando Kant seculariza a moral, "Fica claro, primeiramente, que a exigência da 'preocupação com o outro' e até mesmo, se for o caso, do 'dom de si' não desapareceu das grandes éticas leigas" (FERRY, 2012b, p. 35). $\mathrm{O}$ que nos permite afirmar que não é por ser leiga, secularizada ou, se quisermos, laica, que a moral contemporânea esteja revestida de desumanidade, intolerância, agressividade ou egoísmo, simplesmente porque se desprendeu dos fundamentos religiosos. Mais que isso, essa moral laica debruça-se por fazer calar o egoísmo no homem, lapidando-o. Sobre isso Ferry afirma:

\begin{abstract}
Nossa natureza, volto a insistir, é naturalmente inclinada ao egoísmo, e se quero dar espaço para os outros, se quero limitar minha liberdade às condições de sua integração com a de outrem, então é preciso que eu faça um esforço, é preciso mesmo que eu me violente. E é somente com essa condição que uma nova ordem de coexistência pacífica dos seres humanos é possível (FERRY, 2007, p. 155).
\end{abstract}

Dessa forma, uma moral que se fundamenta na liberdade torna-se o estímulo da vida social através de seu apelo à responsabilidade e da abstração aos particularismos.

Para Ferry, a ética religiosa, diferentemente da ética grega, valoriza o ideal de igualdade, apresentando-nos o homem como "filhos de Deus" e reconhecendo em todos os homens, a capacidade de um crescimento espiritual que contribui com seu aperfeiçoamento humano-cristão a partir dos méritos conquistados em suas ações virtuosas e altruístas. De outro modo, a moral humanista fundamenta essa igualdade entre os homens na liberdade. Nesse sentido Kant afirma:

\footnotetext{
A liberdade, e a consciência desta como um poder que temos de seguir, com uma resolução preponderante, a lei moral, é a independência em relação às inclinações, pelo menos como causas motrizes determinantes (mas não como causas que nos afetam) de nosso desejo; e enquanto tenho consciência dessa independência na observância de minhas máximas morais, ela é a única fonte de um contentamento inalterável
} 
necessariamente ligado a essa consciência (KANT, 2006, p. $145)$.

Ou seja, a moral é fruto da consciência humana, que permite ao homem um voltar-se a si mesmo, tornando-se nesse sentido uma consciência refletida, para assim reconhecer-se, em sua liberdade, semelhante a todos os outros homens. Nesse sentido, a ética humanista defendida por Ferry, afirma que "a dignidade de um ser não depende dos talentos recebidos com o nascimento, mas do que ele faz deles, não da natureza e dos dons naturais, mas da liberdade e da vontade da pessoa humana, quaisquer que sejam seus dotes iniciais" (FERRY, 2012a, p.138). Tem-se assim um deslocamento na valorização da igualdade do homem que migra do ideal religioso de "imagem e semelhança de Deus" para a valorização do homem livre.

Essa valorização da liberdade se efetivou a partir da promulgação da Declaração dos Direitos do Homem e do Cidadão, evidenciando ainda mais, o papel central do homem nessa nova concepção moral:

\begin{abstract}
A declaração dos Direitos do Homem podia ser lida como uma secularização dos valores cristãos. Nela, encontramos expressa a ideia de uma humanidade enfim reconhecida como UMA, assim como a afirmação, sob diferentes formas, da dignidade pessoal de cada ser humano. O fato de o vocabulário dos 'direitos' e do 'indivíduo' sobrepor-se exatamente ao do 'sagrado' e da 'alma' indica suficientemente a amplitude dos deslocamentos, mas também a realidade de uma continuidade (FERRY; COMTE-SPONVILLE, 1999, p. 511-512).
\end{abstract}

Assim, a modernidade não se olvidou de valorizar o homem enquanto indivíduo dotado de uma dignidade porque sua humanidade apresenta-se a nós como sagrada, ou seja, como distintivo do respeito e reverência que devemos ao homem. Não que o homem moderno seja uma divindade ou um ser excepcional, capaz unicamente de belas ações, mas porque o homem é o único ser capaz de humanizar a transcendência a partir da afirmação de valores superiores à vida.

Esse elemento espiritual e racional possibilita ao homem bastar-se a si mesmo no que diz respeito aos embasamentos morais. Kant ilustra bem essa mudança acontecida no campo da ética, pois mesmo postulando a existência de Deus não necessita Dele para fundar a moral. Assim, quanto aos conteúdos, a moral laica permanece íntima da religiosa e a diferença se encontra na nova forma desse conteúdo, no qual a laicidade valoriza o homem, como nos propõe o filósofo crítico, não como um "meio", mas como "fim" o que garante a ele uma singular dignidade.

A própria formulação do Imperativo Categórico, segundo Ferry, retrata a valorização do racional em detrimento de nossos determinismos naturais. Assim, 
como já não se trata de imitar a natureza, de tomá-la como modelo, mas quase sempre de combatê-la, e particularmente de lutar contra o egoísmo natural em nós, é claro que a realização do bem, do interesse geral não é óbvia, que ela se choca, ao contrário, com resistências. Daí seu caráter imperativo (FERRY, 2008b, p. 67).

Vemos assim que para Ferry o Imperativo categórico nos conscientiza acerca de nossa responsabilidade com o outro, aprimorando nossa valorização da transcendência. Aqui, o termo não se identifica com uma divindade, mas simplesmente "essa transcendência do outro que eu sinto na experiência do amor" (FERRY, 2013, p. 93). E Luc Ferry utiliza desse termo porque acredita que o amor "me faz 'sair de mim"” (FERRY, 2013, p. 93), mas, no entanto, é vivenciado na subjetividade mais radical sendo, portanto, imanente a nós. Dessa forma, o sagrado está diante de nós, e não acima da vida, como nos propôs, durante séculos, a tradição metafísica, ou nos termos de Kant, a tradição ontoteológica. Todavia, a grande questão que nos colocamos é a seguinte: $\mathrm{O}$ que faz do homem esse ser tão excepcional, capaz de se tornar sagrado, digno de um amor puramente devotado, a ponto de me sacrificar por ele? E Luc Ferry certamente responderia que aquilo que confere ao homem tal singularidade é a liberdade.

Essa liberdade transcende a subjetividade humana porque permite ao homem "estar sempre em projeto, em projeção, em superação de si, não sendo idêntico a si mesmo" (FERRY, 2012c, p. 203). Dessa forma, o homem pode construir sua própria identidade fugindo de todos os determinismos. De criado, a criador, a liberdade faz do homem "uma exceção na natureza ou, melhor dizendo, no sentido próprio, um ser 'sobrenatural'" (FERRY, 2012c, p. 205).

Mas, a liberdade traz consigo o risco da decadência, ou seja, assim como ela pode ser uma ascese a todos os determinismos, a escolha por ela permitida, quando irrefletida e distante da moralidade, pode culminar nas maiores atrocidades. É nesse momento que a ética desponta como elemento de salvação, e especificamente, uma ética do amor que impulsiona o homem à ação desinteressada, à preocupação com o outro e mesmo a compaixão.

\section{Amor e dever: "ame, ou faça o que deve fazer"}

Como vimos, enquanto a moral se apresenta como um conjunto de imperativos que regem o comportamento humano direcionando-o na prática da justiça e do bem, evocando assim a ideia de dever e remetendo-nos à coerção, o amor se relaciona à gratuidade, porque não coercitivo; à liberdade porque é questão de escolha e abertura; e a uma dimensão superior à moral porque se liga, antes de tudo, à própria grandeza do espírito 
humano. Esse raciocínio pode ser presumido de toda a consideração filosófica de Ferry acerca da moral e do amor.

Se em tudo que fazemos, e porque fazemos, nossa motivação é o amor, temos já, na própria atitude tomada, uma extrapolação a toda coerção moral. Nesse sentido, os imperativos se tornam desnecessários diante da espontaneidade da alma, que impelida pelo amor, resgata o outro do sofrimento que lhe toma. Assim, o Imperativo Categórico de Kant ${ }^{4}$, ganha uma nova formulação: "Não deixa que façam ao outro..." (FERRY, 2012b, p. 149) ou mesmo, "Ame, ou faça o que deve fazer" (FERRY; COMTESPONVILLE, 1999, p. 209), o que evidencia a primazia do amor sobre os fundamentos morais. Neste aspecto, Ferry defende o amor como elemento ético e não moral, ou seja, o amor se relaciona à esfera da reflexão e do espiritual, respondendo-nos à pergunta "o que me é permitido esperar? " $\mathrm{E}$ não à pergunta sobre como devemos agir.

Concomitantemente Comte-Sponville distingue dois princípios que direcionam a atitude do homem, aproximando-se do pensamento de Ferry, a saber, "De um lado, ame, e faça o que quer (é a máxima da ética, pelo menos se se trata de uma ética do amor); e de outro lado: Aja como se você amasse, e faça o que deve fazer (é a máxima da moral, que se impõe quando o amor está ausente) " (FERRY; COMTE- SPONVILLE, 1999, p. 208-209). Assim, a ética se encarrega das questões que se relacionam ao sentido da vida, permitindo um aprimoramento da própria espiritualidade.

A partir disso, o outro se torna valorizado por aquilo que ele é; como um fim em si mesmo, e não como um meio que nos permita alcançar a salvação, algo que Ferry critica veementemente nas ações caritativas cristãs. Afinal, "não era o Outro como tal que se colocava como objeto de qualquer autêntico respeito, mas o cristão em potencial" (FERRY, 2012b, p. 151), ou seja, valoriza-se o outro não por sua humanidade, mas sua pertença à determinada pátria ou religião. A autêntica ação desinteressada pautada no amor valoriza acima de tudo a humanidade do homem, portanto, ama a todos indistintamente.

O amor, ao contrário da tristeza típica do dever, resulta na espontaneidade alegre e assim, no fazer o bem gratuitamente. É por isso que o amor é permissivo, porque amando o outro, somos tomados pelo forte desejo de concretização do bem. Afinal, o amor não nos impele a ações más, e por isso ele não necessita dos imperativos morais para resguardar sua limpidez e excelência, porque "o que fazemos por amor sempre se consuma para além do bem e do mal" (NIETZSCHE, [200-], p.91), visto que no

\footnotetext{
4 "Age de tal modo que a máxima de tua vontade possa sempre valer ao mesmo tempo como princípio de uma legislação universal" (KANT, 2006, p. 47).

${ }^{5} \mathrm{Na}$ obra $O$ homem-Deus ou o sentido da vida, Ferry explica o sentido dessa formulação que assinala o 'algo mais' de universalidade que o humanitário moderno pretende introduzir, ou seja, à capacidade do homem moderno de fazer o bem indistintamente, de forma que cada um se sinta responsável pelo bem do outro.
} 
amor, para além de toda distinção e dualidade racional, agimos no amar. É na simplicidade do amar, e não no complexo e analítico exame das ações, que vemos despontar a gratuidade e o desinteresse em que o amor se manifesta, posto que quando o amor existe, o dever já não é necessário.

Por isso o amor nos direciona ao transcendente na imanência ${ }^{6}$, ou seja, "é ele, em última instância, que dá sentido às nossas vidas. Não apenas porque indica, no seio do $\mathrm{Eu}$ onipotente, um além dele, mas porque esse além se revela um outrem e porque não há sentido fora de uma relação com o outro" (FERRY; COMTE- SPONVILLE, 1999, p. 228). Assim, o amor nos lança para fora de nós mesmos enquanto que a moral nos chama, num sentido oposto, para dentro de nós, para uma autorreflexão e, mesmo, para uma autolimitação; o amor caracteriza-se pela saída, pelo arriscar-se sem visar recompensas, na moral, por sua vez, retraímos nossas ações visando o reconhecimento de outros e a glória pública. Não que a moral não seja necessária, mas ela só será autêntica quando relacionada à gratuidade do amor. Assim, a liberdade associada ao amor atenta-nos para a responsabilidade com o outro.

Não podemos olvidar que a ética do amor, se assim podemos dizer, defendida por Ferry, é uma secularização da ética cristã desenvolvida na patrística. De modo especial, apontamos a proposição de Agostinho: "Ame, e faça o que quer" (AGOSTINHO, 1989, p. 8). Assim, a valorização do amor como um fundamento da ética não aparece somente com o humanismo moderno. Talvez o que se apresenta como novidadeiro é o fato de que a finalidade dessa ação amorosa não é um encontro pessoal com Deus, ou mesmo a conquista da salvação, mas o respeito pelo outro "como um indivíduo em geral, abstração feita de qualquer pertencimento" (FERRY, 2008b, p. 63), ou seja, porque agimos desinteressadamente, e nossa ação, ajuda-nos a significar nossas vidas. Chama-nos a atenção a profundidade dessa exigência ética secular o fato de que o amor se torna gratuidade, fruto da espontaneidade do homem. Nesse sentido a ética da transcendência ${ }^{7}$ desperta em nós uma força de ação que quer afirmar cada vez mais nossa liberdade e nossa humanidade.

Nessa relação com a transcendência é que compreendemos a ligação entre ética e moral. Afinal, para Ferry a moral está acima das determinações

\footnotetext{
${ }^{6}$ Nesse segundo humanismo, proposto por Ferry, a transcendência perde seu valor de exterioridade e verticalidade, passando a se caracterizar como uma transcendência na imanência. Vemos que esse conceito nasce da fenomenologia de Husserl. Nas palavras do autor: " diferentemente da transcendência teológica, essa transcendência fenomenológica não remete à ideia de um fundamento último, situado fora do mundo, mas antes, retomando o vocabulário de Husserl, a ideia de horizontes ou, se preferirem, ao fato de que toda presença nos é dada sobre o fundo de uma ausência, todo visível sobre o fundo de um invisível" (FERRY, 2008b, p. 87).

7 Termo utilizado pelo próprio autor ao tratar dessa valorização de uma ética que se fundamenta no amor. Ferry utiliza o termo sem qualquer relação com o pensamento teológico-ético, mas visando a secularização da mesma.
} 
históricas sendo, portanto, transcendente. E esse caráter da moral resulta do fato de que suas verdades não são criadas por nós, mas se nos impõe como um absoluto, não no sentido dogmático, mas como fruto de nossa reflexão, que longe de nos lançar em nossos desejos subjetivos, permite nosso encontro com o outro. Assim, "é na vida que aparecem valores superiores à vida" (FERRY; COMTE-SPONVILLE, 1999, p. 235).

E no amor vemos a interação da ética transcendente com a moral, encarnada na própria existência do homem. Afinal, quando o amor se torna o fundamento não há o que temer, nem regras a cumprir porque o próprio amor é a regra. E quando se sabe e se vive verdadeiramente esse amor nossas ações se tornam verdadeiras, porque se atua no amor. Nesse sentido, o amor torna-se superior à lei, porque não necessita de seus imperativos para ser. E o sentido mais íntimo da espiritualidade, afirma Ferry, se encontra nessa relação "entre o concreto, o particular de nossas existências e o universal dessas estruturas ideais" (FERRY; COMTE-SPONVILLE, 1999, p. 235). Sobre isso, Comte-Sponville afirma:

Somente quem ama não precisa mais agir como se amasse. É o espírito dos Evangelhos ("Ama e faz o que quiseres"), pelo que Cristo nos liberta da Lei, explica Spinoza, não a abolindo, como queria estupidamente Nietzsche, mas consumando-a ("Não vim para revogar, vim para cumprir..."), isto é, comenta Spinoza, confirmando-a e inscrevendo-a para sempre "no fundo dos corações". A moral é esse simulacro de amor, pelo qual o amor, que dela nos liberta, se torna possível. Ela nasce da polidez e tende ao amor; ela nos faz passar de uma a outro. É por isso que, mesmo austera, mesmo desagradável, nós a amamos (FERRY; COMTE-SPONVILLE, 1999, p. 120).

Esse movimento que o amor nos permite, a saber, de uma evasão do dever em direção à gratuidade, resulta da atitude de amar o amor. Como na moral, só se é possível agir moralmente amando os preceitos morais, para assim, fazer deles motivadores de uma ação que visa o bem e o justo, também o amor exige ser amado para que o homem possa se entregar verdadeiramente ao outro. Assim, antes de amar outrem devemos amar o amor porque ele é o possibilitador de toda mudança e de toda a abertura. Se não amo amar então não amo. Porque não sendo o amor um dever ético ele deve ser objeto de amor para que não se transforme em dever moral. Nesse sentido o amor nos permite uma abertura para o absoluto que se apresenta a nós através dos fundamentos éticos ao que concluiremos que "não é o absoluto que é amor; o amor é que, às vezes, nos abre para o absoluto" (COMTE-SPONVILLE, 2007, p. 190). 
Dessa forma, como defende Ferry, o amor confere sentido à vida e permite-nos a intimidade com os absolutos morais ${ }^{8}$, porque é somente a partir deles que somos capazes de todo o resto. Nesse sentido o amor é primeiro, mesmo que sendo amor a si mesmo, e o sendo, sabe de sua capacidade de agir em vista do bem.

\title{
4. Do cristão ao laico: Ágape como fundamento
}

Esse amor que vem primeiro, segundo Ferry, se identifica com Ágape que apesar de possuir sua conotação religiosa, não se limita unicamente à essa experiência. Como um grande defensor da laicidade e dos fundamentos iluministas, o autor seculariza essa forte experiência do amor cristão gratuito e desinteressado identificando-o com o amor parental entre pais e filhos, afinal "o amor pelos filhos é o mais especial de todos. Talvez ele seja o único a nos dar uma imagem real do agape" (FERRY, 2012a, p. 331). É, portanto, na relação com os filhos que é possível uma experiência secular de ágape. Dessa forma, Ferry acredita que tenha conseguido desvencilhar de toda a denotação religiosa a prática do amor cristão de forma que, até mesmo ao não crente ou ao agnóstico, também é possível tal experiência de amor desinteressado.

Um fato marcante na vida de Ferry que o despertou para a experiência desse amor agápico foi a adoção de sua filha Gabrielle e, posteriormente, o fato de ter mais duas filhas, Louise e Clara, tal experiência afirmou-se mais. É daí que o autor passa a acreditar na existência do amor agápico, que já havia conhecido, nas pregações e catequeses dos padres, em sua infância. Diz-nos o autor:

\begin{abstract}
Na teologia cristã, ágape vai muito longe: em princípio, vai até o amor pelo inimigo. Durante muito tempo, quando eu era criança e ia ao catecismo, não compreendia (e acho que o padre não compreendia mais do que eu...) o que podia querer dizer esse pretenso 'amor pelo inimigo'. Não via como o judeu pudesse amar o nazista que exterminava na frente dele sua família; não compreendia como se podia pretender seriamente amar o carrasco. Não via (e acho que tenho razão em grande parte) senão um 'discurso de padre' sem nenhuma ligação com a realidade (FERRY, 2013, p. 69).
\end{abstract}

Ao que parece, Ferry não acreditava na possibilidade de Ágape porque não via nos discursos religiosos mais do que uma bela ilusão utópica. Amar o inimigo e perdoar todo o tipo de ofensas traduzia uma imagem inacessível de experiência de amor para o homem. O ideal de santidade proposto no amor agápico, no entanto, foi experimentado pelo

\footnotetext{
${ }^{8}$ Para Luc Ferry os princípios éticos são absolutos porque não negociáveis, assim como, não são criados pelo homem.
} 
autor no que aparentemente era banal, ou seja, a paternidade. No entanto, é através dos evangelhos que Ferry consegue compreender intensamente a lógica de ágape: segundo o autor, a metáfora usada por Cristo da importância das crianças como referencial para a entrada no reino dos céus nos permite entender ágape como um amor que exige não somente imitarmos as crianças, mas amá-las apesar de qualquer adversidade (FERRY, 2013, p. 70). Trata-se de um amor gratuito que nada espera em troca e que diferente do amor erótico, não espera retribuição exigindo sempre mais ser amado, "amamos sem nada pedir, sem exigência de retorno, simplesmente para fazê-las felizes, para protegê-las, para vê-las crescer, em resumo, mais por elas do que por nós" (FERRY, 2012a, p. 332). Neste aspecto, tem-se claramente a secularização da teoria do Tsimtsum recordada e analisada por Simone Weil, no qual a Ágape, mesmo secularizada, é esse amor sem reciprocidade e mesmo sem exigência, ou seja, é graça porque assim como Deus "deixou que lhe faltasse ser para que houvesse ser" (FERRY, 2012c, p. 125), o amor que um pai tem por seu filho fá-lo negar a si mesmo para que o filho seja.

Em certo sentido, trata-se de uma experiência bem banal: todos os pais recentes reconhecem que a paternidade profundamente revira a hierarquia dos valores. Mas o banal não se exclui da filosofia e me pareceu que esta última não pode se manter apenas no terreno da teoria, da moral ou do direito: foi preciso pensar essa particularidade do amor como fator de sentido (FERRY, 2012c, p. 125).

Justamente por ser tão comum o sentimento que os pais devotam a seus filhos é que o homem moderno consegue ultrapassar-se a si mesmo, partindo da esfera da intimidade da vida familiar para a esfera do coletivo e social. E esse amor, diferente de todos os outros amores já experimentados, desperta o autor para questões mais complexas, como a morte dos entes queridos e a própria finitude da relação parental. Tais dilemas estão relacionadas, segundo Ferry a experiências mais profundas como a própria vida espiritual do homem. Por isso, o amor se apresentará para ele como o elemento central de uma espiritualidade laica, sem Deus, mas não menos cristã.

No entanto, vemos na proposta de Ferry um reducionismo que exclui as demais formas de amor como garantias de um autêntico desapego do eu e sacrifício em favor dos outros. Em sua obra $A$ revolução do amor, o autor chega a afirmar: "Não adianta termos amado irmãos e irmãs, pais, mulheres, homens ou amigos, não sabemos o que é amar verdadeiramente, em todo caso, o que é o ágape, antes de termos filhos" (2012a, p. 332). Dessa ocular do autor poderemos então concluir que aqueles que nunca tiveram filhos, ou porque optaram em não os ter ou porque impossibilitados de tê-los, por diversos outros fatores, inclusive os biológicos, estão fadados a nunca 
amarem verdadeiramente e nem mesmo conhecerem o que é a experiência do amor agápico segundo o modelo secular. Esses mesmos homens e mulheres, ao que parece, estariam destinados a amar unicamente a si mesmos tornando-se insensíveis às dores e sofrimentos do mundo, afinal, é o amor paterno a porta de abertura a todas as demais experiências autênticas do amor desinteressado. Certamente todos aqueles que vivem a experiência paterna ou materna podem encontrar sentido nas colocações do autor, mas não podemos nos esquecer, da mesma forma, tantos homens e mulheres que tendo vivenciado a experiência da paternidade ou da maternidade, ao invés de desenvolverem esse sentimento agápico, tornam-se, do contrário, verdadeiros carrascos de seus filhos, chegando em casos extremos, a matar sua prole. Dessa forma, a teoria de Ferry, nos dizeres de Popper, não sobreviveria ao critério da falsificabilidade, tendo em vista a existência de muitos elementos que derrubam a veracidade da afirmação de que o amor parental é a única experiência verdadeira do amor agápico, mesmo em se tratando de uma experiência secular, já que a mesma não exclui a singularidade agápica das ações caritativas e do amor aos inimigos, ainda quando esse nos parece inacessível.

Todavia, voltando-nos à ótica de Ferry, tem-se que o amor agápico secularizado também se concretiza nas ações humanitárias e numa política do amor no qual a vida privada e a experiência familiar permitem um novo horizonte de ação que valoriza acima de tudo a humanidade e suas mazelas. Assim,

\begin{abstract}
o cuidado com as pessoas prevê que o político não deixe de lado os horizontes mais amplos, que inclusive a sua plena consideração se torne para ele um dever. Só que essas preocupações clássicas com os grandes negócios do mundo ganham uma nova coloração: não são mais um fim em si mesmo, ou melhor dizendo, estão menos a serviço da Nação, com ' $\mathrm{N}$ ' maiúsculo, do que daqueles que a povoam. $\mathrm{E}$, no ponto de vista da história, isso é radicalmente inédito. Os políticos, aliás, o pressentem, como se pode ver, por toda a Europa, pela proliferação dos debates de sociedade: sobre os sem-teto, a crise habitacional ou as dificuldades cotidianas dos transportes, por exemplo (FERRY, 2008a, p. 127).
\end{abstract}

Destarte, para Ferry a valorização de Ágape permite a humanização da própria política mudando toda a lógica do primeiro humanismo, afinal, não são mais os indivíduos que devem servir cegamente à pátria como se ela fosse um valor absoluto a ser respeitado, pelo contrário, a pátria passa a estar a serviço do homem. Portanto, vida privada e vida pública tornam-se intimamente ligadas pelas vias do amor. Nos dois âmbitos, o amor tem provocado revoluções a ponto de fazer com que os particularismos sejam superados. Dessa forma, 
o individual não se opõe ao coletivo, nem a vida privada à vida pública. Assim que essa última se torna auxiliar da primeira, assim que ela se coloca a seu serviço como toda a história da família moderna tende a mostrar ser imperativo, ela deve tirar partido do fato de que nossos problemas individuais são, quando considerados em conjunto, eminentemente coletivos. [...] de modo que o individual, longe se de afastar do coletivo, é apenas seu rosto encarnado. Procurando assumi-lo, a política não se afasta de sua missão, muito pelo contrário: só então ela começa realmente a cumpri-la, pois o coletivo que ela há pouco passou a notar e que, no fundo, é apenas o singular elevado ao universal, é o seu alfa e seu ômega (FERRY, 2008a, p. 134-135).

Essa relação do privado e do público nos mostra ainda mais a valorização dos filhos porque afirma que nossas preocupações políticas, segundo Ferry, é também e acima de tudo, preocupação com o mundo que os pais deixarão para seus filhos. Nessa atitude tem-se claramente concretizado aquilo que Ferry chamará de pensamento expandido ou mentalidade alargada, algo que o amor nos permite e que se torna a base de toda a tarefa moral e filosófica e mesmo, de toda a dimensão salvífica garantida pelo amor.

Quando expandimos o pensamento alcançamos, nas palavras de Ferry, uma "universalidade individual", ou seja, arrancamo-nos de nossa particularidade "e nesse ponto a que é tão difícil chegar, conhecer e amar tornam-se uma só e mesma coisa. Nesse ponto, não há mais distância entre o relativo e o absoluto, entre o particular e o universal, entre o conhecimento e o amor" (FERRY; COMTE-SPONVILLE, 1999, p. 238). Assim, torna-se possível uma reconciliação do homem com o mundo e ainda mais, a reconciliação do homem com a humanidade inteira. Afinal, a mente alargada nos faz homens e mulheres singulares e essa singularidade não se confunde, em hipótese alguma, com a individualidade. Ser singular é ser insubstituível, distinto de todos os outros, e ao mesmo tempo capaz de se identificar com o outro que não sou. É nesse sentido que o particular e o universal se entrelaçam. E Ferry explica:

Creio apreender o coração de um ser, sua mais íntima intimidade ao amá-lo por suas qualidades, mas a verdade é outra totalmente diferente: aprendi dele tão-somente atributos tão anônimos quanto uma carga ou uma decoração, e nada mais. Em outras palavras, e retomo aqui o fio de nossa colocação: o particular não era o singular. De fato, somente a singularidade que ultrapassa a um só tempo o particular e o universal pode ser objeto de amor. Caso nos atenhamos apenas às qualidades particulares/gerais, nunca amamos ninguém[...] $\mathrm{O}$ que faz de um ser um ser amável, o que dá o sentimento de poder escolhê-lo entre todos e continuar a amá-lo mesmo depois de a doença o ter desfigurado é por certo o que o torna insubstituível, ele e não outro (FERRY, 2008b, p. 222). 
Dessa forma, o que amamos no outro é aquilo que o distingue e o faz único em meio aos demais. E essa compreensão da singularidade só nos é possível quando somos capazes de sair de nossa individualidade exacerbada. É por isso que o amor se torna fundamento da vida espiritual laica, porque a busca pelo transcendente não se dá mais no sentido vertical, mas na horizontalidade, ou seja, no encontro com o outro. Um encontro que nos tira de toda a falta de sentido e que, portanto, nos salva de uma vida insignificante e fútil. Somente no amor, experiência do transcendente na imanência, poderemos nos redimir e nessa caminhada teremos como guia a própria filosofia.

\title{
5. A filosofia como soteriologia
}

Compreender a salvação na ocular filosófica é garantir sentido à existência humana, ou mesmo, permitir que tenhamos uma vida boa e bemsucedida, não em termos estritamente materiais, mas no que tange à própria experiência espiritual do homem principalmente ao lidar com as perturbações diárias. Luc Ferry diz:

\begin{abstract}
A pergunta sobre a 'vida boa', sobre aquilo que vale realmente nessa nossa existência, e não numa outra, merece ser feita - e todos os grandes filósofos confrontam-se com ela - justamente porque vamos morrer e porque sabemos disso, porque vamos perder quem nos é próximo e porque a banalidade ameaça ininterruptamente a existência quotidiana. Desse modo, por mais chocante que isso possa parecer hoje, talvez a vida e o pensamento tenham sempre partilhado da problemática da salvação (FERRY, 2004, p. 29).
\end{abstract}

Mesmo que a questão da salvação pareça um problema a ser abordado única e exclusivamente pela teologia, veremos que na filosofia essa abordagem salvífica ganhará outros contornos, fazendo da salvação um problema do próprio homem e não de uma dependência em relação a um ser superior, ou seja, não se trata de sermos salvos, mas de salvar-nos a nós mesmos. Nesse ínterim, afirma Ferry, caberá à filosofia essa tarefa de direcionar o homem na busca das respostas aos seus sofrimentos e angústias, a seus projetos e também à sua finitude.

A filosofia sempre foi, pelo menos em seus maiores momentos, secularização de uma religião; ela é sempre parte de uma representação religiosa do mundo e das relações entre os homens e os deuses e, essencialmente, ela sempre agiu para secularizar, laicizar a mensagem religiosa (FERRY, 2012d, p. 39). 
Ao secularizar as questões que até então pertenciam somente à religião, a filosofia tem por tarefa, dar ao homem a total liberdade no direcionamento da sua própria vida e das escolhas que traça para concretizar seus projetos. Assim, a filosofia como percurso de salvação é ao mesmo tempo caminho de liberdade, coragem que derrota os medos, aceitação da morte, e não somente daquela que põe fim à nossa vida ou na dos que amamos, mas também nas mortes diárias, que dissolvem nossos projetos e relega-os ao fracasso.

A aceitação deve ser, portanto, um dos aspectos que sustentará a busca do sentido da vida. Não existindo mais vida eterna nem Deus, não existindo mais o paraíso que nos garante o reencontro com cada um daqueles que amamos, todo e qualquer sentido parece se esvair. Para Ferry, quando o homem aceita sua finitude e reconhece que o paraíso já é aqui, então o processo soteriológico já se inicia. A crença já não faz sentido porque o que nos motiva não é a esperança, mas sim o amor e o amor exigem ação sem espera, e liberdade espiritual.

De outro modo, a filosofia é um suporte soteriológico porque garante ao sábio a consciência de sua vulnerabilidade e das circunstâncias a que está submetido, tendo em vista que a sabedoria também consiste no reconhecimento de que

[...] nada, no mundo humano, é permanente. O único elemento eterno é a própria 'impermanência', a característica flutuante e mortal de toda coisa. Quem for louco o bastante para ignorar isso se expõe aos piores sofrimentos. Se tomarmos consciência das verdadeiras causas do mal, se percebermos que provêm das ilusões de um eu que se prende a suas 'posses', enquanto a lei do mundo é a das trocas, podemos conseguir nos libertar. Essa é a sabedoria (FERRY, 2012b, p. 10).

Dessa forma, sob a ocular de Ferry, temos que a sabedoria é necessária no processo redentor do homem. Trata-se de uma redenção conquistada pelo homem na liberdade e na capacidade de ser consciente de seus limites. Assim, não é necessário que Deus se faça homem no intuito de oferecer a salvação aos que jaz sufocado pelo pecado. De outro modo, a salvação se dá na perspectiva da vida boa. "Sendo assim, as grandes filosofias puderam poupar-se de uma relação com o absoluto, ainda num sentido agnóstico e até mesmo antirreligioso. Para elas, trata-se justamente do absoluto, não de meias medidas, de acordos ou de subterfúgios" (FERRY, 2004, p. 31), mas de uma relação factual com aquilo que vale absoluta e não relativamente para o homem.

Desse modo, a filosofia não poderá escamotear a questão da finitude do homem e da urgente necessidade que temos de valorizar, em absoluto, nossas mais nobres relações, erradicando, segundo Ferry, as respostas fáceis da religião e promovendo a atividade reflexiva do homem. Assim, aceitar os deuses como sagrados é mais cômodo do que pensar o sagrado no mundo e 
nas situações corriqueiras da vida porque "é mais cômodo sacrificar-se pelas nostalgias do paraíso perdido do que 'pensar o que é' para nós, aqui e agora" (FERRY, 2004, p. 33). Por isso o sagrado, bem como a salvação favorecida pela filosofia nos exige descartar a visão cristã de que o mundo é o lugar onde nenhum sentido é possível porque é o lugar da decadência, do padecimento e do sofrimento, e mais que isso, descartar a ideia de que a vida eterna é o coroamento e o sentido último do existir do homem. Essa foi, afinal, a grande crítica de Nietzsche ao cristianismo: querer fazer do mundo o lugar de todos os sofrimentos, culpabilizando todo aquele que sabe viver intensamente o presente.

A garantia de significação da vida, nos dirá Ferry, ao contrário, só é possível no presente pois é na experiência diária, no contato diário com as pessoas e na concretização dos projetos que traçamos para nós, que surge o sentido de viver. Afinal, se o futuro ainda não é e o passado já não é mais, neles nenhum sentido poderá ser garantido. Por mais que sejamos o resultado de nossos atos passados e que no presente eles traduzam certa parcela do que somos, não podemos nos prender ao já realizado porque corremos o risco de estagnar o presente, este que é o tempo do sentido porque nele temos a garantia de poder realizar e mudar, de agir e amar, e se não o fizermos estaremos condenados a viver uma vida angustiante e sem sentido.

Além disso, a filosofia torna-se também amparo para aqueles que se desesperam diante da velhice. Como encontrar um sentido para a vida quando parece que o homem caminha, a passos longos, para a imperfeição? Ou seja, o que temos diante de nós não é a juventude, mas a velhice; não é a vida eterna, mas a morte como um fim real; não a saúde plena, mas o limite corporal. Diante dessa contradição que nos assola diariamente: somos dotados da faculdade de aperfeiçoamento, manipulamos cosméticos que disfarçam nossa idade, mais que isso, desenvolvemos técnicas de intervenção cirúrgica que nos permite o rejuvenescimento, mas mesmo assim, não conseguimos fugir à decadência. Para aqueles que se desesperam diante da velhice parece que toda a busca de sentido, portanto, não faz sentido, e que todo sentido buscado resultará em uma vida decadente, resultando-nos o incômodo questionamento: "O que fazer do declínio, sendo a vocação do homem o progresso?" (FERRY, 2012b, p. 14)

Vemos no homem moderno uma fuga constante do enfrentamento da realidade. Um dos grandes problemas é que superexaltamos a juventude como o momento mais promissor da vida humana e identificamos a velhice como decadência e improdutividade. No entanto, não podemos negar, todos envelhecemos e a partir de então a questão da velhice se torna uma grande questão espiritual. Nesse momento a filosofia vem nos salvar dessa eventual situação de decadência porque é a sabedoria, segundo Ferry que permite, através da individuação que aperfeiçoamos no decorrer da vida, experimentar a temporalidade como eternidade. Esse processo de 
individuação é possível graças à expansão do pensamento, como vimos no tópico anterior, que nos retira do particular e permitindo-nos o acesso ao universal. Sobre essa relação nos diz Ferry:

\footnotetext{
Quando faço o elogio da velhice ou quando faço, digamos, o elogio da sacralidade da humanidade, não é nem para dizer que a velhice é sensacional, nem para dizer que a humanidade é sensacional, mas sim para dizer que é o preço a pagar para alcançar essa individualidade concreta que tem a particularidade de não se fechar em si mesma, mas, ao contrário, entrar cada vez mais em relação com os outros. Quanto mais se é um indivíduo, mais se é universal, se assim posso dizer (FERRY; COMTE-SPONVILLE,1999, p. 301).
}

E quando nos individualizamos, expandimos o pensamento e nos universalizamos estamos aprimorando nossa dimensão espiritual, acima de tudo porque não nos fechamos em nós mesmos, mas conseguimos deslocar da centralidade de nossa existência nosso ego limitador. Assim, a velhice se torna questão de espiritualidade para os laicos porque ao nos depararmos com ela, ou mesmo, ao vivencia-la o homem se torna capaz de abraçar a causa do outro, seus problemas e sofrimentos. Isso porque a velhice traz em si um acúmulo de experiências e o reconhecimento de que os mesmos sofrimentos que abatem o outro, em dado momento, poderá se abater sobre nós com proporções distintas, mas carregado da mesma angústia e debilidade.

Este aspecto, como tantos outros que tocam os questionamentos existenciais, introduz na filosofia a preocupação com a salvação do homem. De fato, nos mostra Ferry, a salvação garantida pela filosofia não se identifica, em nenhum aspecto, com a promessa da bem-aventurança, mas como vimos, com o reconhecimento de que é necessário buscar um sentido para viver e fugir de todo o niilismo decadente. Mais que isso, é necessário o aprimoramento da espiritualidade, e através dela, evadir-se da angústia que as realidades da vida, muitas vezes banais, trazem consigo. Portanto, trata-se antes de mais nada de questionar nossa natureza finita a partir da razão e não da fé porque "a fé limita o homem; ela lhe toma a liberdade e a capacidade de valorizar devidamente o outro, o que lhe é diverso. A fé é presa em si mesma" (FEUERBACH, 2007, p. 247). E na mesma lógica de Feuerbach podemos incluir toda filosofia dogmática que se sobrepõe à espiritualidade do homem relegando-a à questões teológicas.

\section{A filosofia como discurso do espírito}

Ao se dissociar na filosofia, muitos conceitos e experiências religiosas também se tornaram laicos. A própria maneira de compreender o sagrado ganha novos contornos deixando de ser um elemento transcendente e fora do mundo, superior ao homem e soberano, muitas vezes identificado 
com o próprio Deus, passando a ser identificado com algo tão banal como o amor que sacraliza as relações e a própria figura humana, estando imerso no mundo e sendo acessível a cada um de nós. Então, nem mesmo a dimensão espiritual ficará limitada a uma interpretação religiosa podendo ser vista sobre o prisma da razão e da laicidade, bem como a espiritualidade terá por pressupostos a reflexão, a harmonia com a ciência e a liberdade do homem. É nesse sentido que poderemos falar de espiritualidade laica, espiritualidade ateia e mesmo, espiritualidade cética.

Vários são os autores que tratam de uma espiritualidade que excede às determinações religiosas ${ }^{9}$, e em comum, ambos valorizam a ideia de que essa dimensão espiritual se identifica com a vivência do real e do tempo presente. $\mathrm{O}$ que nos permite afirmar que a espiritualidade é uma dimensão natural do homem e por sê-lo, não está relegada a uma experiência de eternidade em outra vida nem mesmo a práticas estritamente religiosas, porque assim sendo, baniria da vida dos não crentes essa dimensão espiritual. É por isso que o espiritual não pertence unicamente à religião institucionalizada, mas também à filosofia, o que não é bem aceito por muitos filósofos contemporâneos, principalmente aqueles que se debruçam sobre a filosofia analítica e desprezam qualquer relação entre filosofia e espírito por acreditar que as coisas do espírito cabem unicamente ao imaginário e ao não provado ${ }^{10}$. No entanto, a espiritualidade nos remete a certos questionamentos que só encontram respostas adequadas sob o respaldo da filosofia. Ou seja, é quando nos questionamos, não somente sobre a contradição entre amor e morte ou sobre o sentido que damos à nossa vida como nos propõe Ferry, mas, quando nós fazemos questionamentos mais complexos sobre nós mesmos e nossa relação com o mundo e as outras pessoas, temos já o alvorecer de nossa dimensão espiritual. Assim, perguntas como:

Podemos ao mesmo tempo nos respeitar e adotar o tipo de humildade que nos põe no lugar certo no mundo? Como podemos aprender a pensar sobre nós mesmos em termos de nossas relações com outras pessoas, em termos de compaixão e Espírito partilhado, em contraste com nosso individualismo aquisitivo? Como podemos chegar a um acordo com as forças impressionantes e por vezes aterrorizantes em ação no mundo sem reduzi-las a tolices econômicas, políticas, conspiratórias ou apocalípticas? Como podemos cultivar as paixões nobres e exorcizar as banais (ou pelo menos limitar seu dano)? Como podemos conservar uma noção do quadro geral enquanto nos

\footnotetext{
${ }^{9}$ Dentre outros, destacamos Comte-Sponville, Robert Solomon e Marià Corbí.

${ }^{10}$ Esse embate entre filosofia e espiritualidade, ou mesmo, da filosofia analítica e crítica e espiritualidade é desenvolvido por Robert Solomon na obra Espiritualidade para Céticos (2003). Também Ferry realiza tal constatação afirmando que os filósofos se interessam unicamente pelas questões morais, políticas e científicas, desvalorizando o espiritual. Para isso ver: $O$ anticonformista (2012).
} 
deixamos absorver por nossas esperanças, nossos medos e nossas aspirações, e pelos estados de ânimo e modas do tempo? (SOLOMON, 2003, p. 29-30)

Essas indagações, como vemos, nos levam a uma dimensão bem mais profunda do que o simples questionamento fideísta ou racionalmaterialista. Todas essas questões tocam nosso ser mais profundo, nos desloca fazendo-nos perceber que o espírito em nós, mesmo não sendo religioso, não se cala porque "não ter religião não é um motivo para renunciar a toda vida espiritual" (COMTE-SPONVILLE, 2007, p. 127). Afinal, e como vimos afirmado por Ferry, estando a espiritualidade entranhada na existência do homem e a todas as questões relativas a essa mesma existência, não poderia ela estar distante da filosofia que em toda a sua história consiste numa "sabedoria do amor, uma definição da vida boa ou uma espiritualidade leiga, sem passar por Deus nem pela fé" (FERRY, 2012c, p. 312-313). Mas, a visão de espiritualidade do autor é demasiado rasa, carente de embasamentos sólidos e considerações mais profundas, afinal, a vida do espírito é mais do que a mera preocupação com a morte e uma consequente estruturação da vida boa, trata-se de uma dimensão que retrata a própria experiência que o homem tem de si, um grau de consciência de seu eu que não se limita a um egocentrismo, mas que permite, a partir do reconhecimento o esvaziamento de si mesmo.

É sabido que Ferry defende essa perspectiva altruísta da espiritualidade através do amor e das ações caritativas, no entanto, parecenos que a espiritualidade não pode ser somente isso, nem mesmo uma simples atitude de pensar e refletir, mas "é o poder de pensar na medida em que tem acesso ao verdadeiro, ao universal" (COMTE-SPONVILLE, 2007, p. 128) e assim,

[...] se espiritualidade significa alguma coisa, significa reflexão. [...], mas reflexões sobre o significado da vida e os sentimentos profundos que essas reflexões engendram. [...] A espiritualidade, como a filosofia, envolve aquelas indagações que não têm respostas definitivas, por mais desesperadamente que nossas várias doutrinas e dogmas tentem fornecê-las (SOLOMON, 2003, p. 31).

E nessa reflexão abissal sobre o que a própria vida representa, o homem se depara com diversas situações em que a espiritualidade se torna, na ocular de Ferry, o reforço do homem no enfrentamento das variadas circunstâncias que a vida nos apresenta. Dessa forma, a espiritualidade para Ferry será lucidez porque através da reflexão passamos a enxergar nossa verdadeira situação de contingência; a espiritualidade é também coragem, porque não nos permite incorrer no medo que paralisa a própria vida do homem; e por fim, a espiritualidade é a conscientização do homem quanto à necessidade de se desprender das imaginações do passado ou das esperanças 
do futuro imprimindo no espírito desse mesmo homem a certeza de que a vida em sua singularidade exige de nós simplesmente "viver o presente, habitar o aqui e agora" (FERRY, 2012a, p. 241) e assim "experimentar a eternidade" (FERRY, 2012a, p. 241) que subsiste mesmo quando o paraíso celeste não faz sentido.

\section{Considerações finais}

O reconhecimento da pura humanidade que nos constitui, reafirma a preocupação que devemos nutrir uns pelos outros. Para Ferry, um humanismo tão humano só poderá se embasar no sentimento mais verdadeiro e recíproco, que leva o homem a sair de si em favor do outro, a saber, o amor.

Dessa forma, o amor se torna o fundamento e o doador de sentido para todos nós porque é ele que possibilita a anulação de qualquer moral e mesmo, qualquer princípio religioso, que nos determina a agir por coação. Trata-se de um amor que se expressa em atitudes autênticas, verdadeiras, desinteressadas, ilimitadas, que ultrapassam o discurso hedonista e leva o homem a agir em favor dos seus. Em ágape, o amor por excelência, o homem consegue alcançar a alteridade. Esse amor convoca-nos à responsabilidade porque nos permite a realização do bem pelo bem e não por interesse. É ainda através do amor que a transcendência imanente não nos é imposta como lei nem mesmo nos vem da exterioridade, mas brota da própria interioridade do homem lançando-nos para fora de nós mesmos.

No entanto essa transcendência está também em nós, há algo que, não visível, nos possibilita compreender além da percepção. Essa transcendência não requer uma desvinculação com a imanência, na verdade, ela é que nos permite compreender a banalidade do cotidiano significando-o de forma inédita. Esse fora de nós se identifica também com a humanidade que permeia nossas relações e que desperta nossa consciência para o respeito a todos os homens. Trata-se de uma ética humanista da responsabilidade alicerçada no amor pelo próximo. Aqui o homem se torna, segundo Ferry, sacralizado a partir de sua humanidade. Quanto mais se humaniza mais se diviniza.

Tal divinização do homem é resultante da concepção de uma ética secular, proposta por Ferry, que leva em consideração a afirmação sempre crescente da preocupação com toda a humanidade no âmbito laico. No entanto, sua formulação filosófica, como vimos, não escapa dos conceitos religiosos. Daí podermos afirmar que, os valores cristãos embasam toda sua filosofia, a ponto de o autor afirmar a possibilidade de uma espiritualidade laica. No entanto, não se trata de um discurso dogmático institucionalizado, mas da valorização do homem num humanismo secular-cristão, se assim podemos dizer. O próprio discurso do autor acerca da centralidade do amor como fundamentação de toda a ação ética nos remete aos ensinamentos 
cristãos da valorização de ágape, do sacrifico de si pelo próximo em busca da eternidade. Diferente dessa concepção, Ferry nos mostra que a ação ética ultrapassa as recompensas prometidas pelas religiões visando a consciência do homem e sua total responsabilidade em relação à alteridade na eternidade presente, que é a vida. Nesse sentido, a ética humanista, por mais secular que seja não pode fechar os olhos aos valores cristãos que continuam a fundamentá-la.

\section{Referências bibliográficas}

AgOSTINHO, Santo. Comentário da primeira epistola de São João. Trad. de Nair de Assis Oliveira. São Paulo: Paulinas, 1989.

COMTE-SPONVILLE, André. O espírito do ateísmo. São Paulo: Martins Fontes, 2007.

FERRY, Luc. A revolução do amor, por uma espiritualidade laica. Rio de Janeiro: Objetiva, 2012a.

Aprender a viver. Rio de Janeiro: Objetiva, 2007.

2013.

Do amor, uma filosofia para o século XXI. Rio de Janeiro: DIFEL,

- Famílias, amo vocês, política e vida privada na época da globalização. Rio de Janeiro: Objetiva, 2008a.

. O anticonformista, uma autobiografia intelectual; entrevistas com

Alexandra Laignel- Lavastine. Rio de Janeiro: DIFEL, 2012c.

$2012 b$

O homem-Deus, ou, O sentido da vida. Rio de Janeiro: DIFEL,

O que é uma vida bem sucedida? Rio de Janeiro: DIFEL, 2004.

Vencer os medos, a filosofia como amor à sabedoria. São Paulo:

Martins Fontes, 2008b.

; COMTE- SPONVILLE, André. A sabedoria dos modernos, dez questões para o nosso tempo. São Paulo: Martins Fontes, 1999.

; JERPHAGNON, Lucien. A tentação do cristianismo, de seita a civilização; Rio de Janeiro: Objetiva, 2012d.

FEUERBACH, Ludwig. A essência do cristianismo. Petrópolis: Vozes, 2007.

KANT, Immanuel. Crítica da razão prática. São Paulo: Escala, 2006.

NIETZSCHE, Frederich. Para além do bem e do mal, ou prelúdio de uma filosofia do futuro. Curitiba: Hemus, [200-]. Disponível em: http://ghiraldelli.pro.br/wp-content/uploads/alem-do-bem-e-do-mal.pdf.

Acesso em 23/04/2015.

SOLOMON, Robert C. Espiritualidade para céticos. São Paulo: Civilização

Brasileira, 2003. 